Data Article

\title{
Data on the corrosion Inhibition Property of Rosemary on High Carbon Steel in dilute sulphuric acid, citric acid and sodium chloride solution
}

\author{
O.A. Odunlami ${ }^{\mathrm{a}, *}$, R.T. Loto ${ }^{\mathrm{b}}$, M.A. Fajobi ${ }^{\mathrm{b}, *}$, O.T. Olomukoro $^{\mathrm{a}}$, I.G. Akande ${ }^{\mathrm{c}}$, \\ M.A. Oke ${ }^{\mathrm{d}}$, T.E. Oladimeji ${ }^{\mathrm{a}}$ \\ a Department of Chemical Engineering, Covenant University, Ota, Ogun state, Nigeria \\ ${ }^{\mathrm{b}}$ Department of Mechanical Engineering, Covenant University, Ota, Ogun state, Nigeria \\ ${ }^{c}$ Department of Mechanical Engineering, University of Ibadan, Ibadan, Oyo state, Nigeria \\ d Department of Chemical Engineering, Obafemi Awolowo University, Ile-Ife, Osun state, Nigeria
}

\section{A R T I C L E I N F O}

\section{Article history:}

Received 24 September 2020

Revised 19 November 2020

Accepted 9 February 2021

Available online 2 March 2021

\section{Keywords:}

Corrosion rate

Citric acid

Sulphuric acid

Sodium chloride

High carbon steel

Organic compound

\begin{abstract}
A B S T R A C T
The data of electrochemical analysis of Rosmarinus officinalis (RO) essential oil effect on high carbon steel (HCS) in three different corrosive environment of sodium chloride, sulphuric acid and citric acid solution was achieved via weight loss method. Results revealed that Rosmarinus officinalis (RO) organic compound performed excellent well on high carbon steel samples with the optimum inhibition value occurring in $\mathrm{NaCl}$ solution with $97.87 \%$ after $504 \mathrm{~h}$. The corrosion rate values were significantly high at $0 \mathrm{ml}$ RO organic compound for all the three (3) corrosive environments as the time of immersion moves down to $504 \mathrm{~h}$. It was clearly observed that time of immersion and concentrations of RO are the main determinant factor for the excellent adsorption performance of RO organic compound within the range of $504 \mathrm{~h}$. Also, Rosmarinus officinalis (RO) organic compound retarded the severe corrosion rate of high carbon steel samples in other corrosive solutions with average range inhibition values between 40 and $78 \%$ after $504 \mathrm{~h}$.
\end{abstract}

(c) 2021 Elsevier B.V. All rights reserved.

\section{Specification table}

\begin{tabular}{|c|c|}
\hline Subject area & Chemistry \\
\hline Specific subject area & Material Science, Corrosion \\
\hline Type of data & Tables \\
\hline How data was acquired & $\begin{array}{l}\text { The Ohaus analytical balance was used to determine weight loss of each sample from which the corrosion rate and } \\
\text { inhibition efficiency was calculated }\end{array}$ \\
\hline Experimental factors & $\begin{array}{l}\text { The steel samples were cut mechanically and grounded with abrasive paper (silicon carbide), rinsed with distilled } \\
\text { water and acetone and dried for weight loss measurement. }\end{array}$ \\
\hline Data format & Analysed \\
\hline Experiment features & $\begin{array}{l}\text { Corrosion rate and inhibition efficiency data were obtained at every } 24 \mathrm{~h} \text { with the period of } 504 \mathrm{~h} \text { of the high } \\
\text { carbon steel in sodium chloride, sulphuric acid and citric acid solution at specific concentrations of Rosmarinus } \\
\text { officinalis (RO) organic compound for the complete time of } 504 \mathrm{~h}\end{array}$ \\
\hline Data source location & Ota, Ogun State, Nigeria \\
\hline Data accessibility & The data is with this research article \\
\hline
\end{tabular}

* Corresponding authors.

E-mail addresses: olayemi.odunlami@covenantuniversity.edu.ng (O.A. Odunlami), fajobi.muyiwa@covenantuniversity.edu.ng (M.A. Fajobi). 
Table 1

HCS composition [21].

\begin{tabular}{llllll}
\hline Element & $\mathrm{C}$ & $\mathrm{Mn}$ & $\mathrm{P}$ & $\mathrm{S}$ & $\mathrm{Fe}$ \\
\hline \% Content & 0.90 & 0.50 & 0.04 & 0.05 & 98.51 \\
\hline
\end{tabular}

Table 2

Chemical Composition of RO essential oil [22].

\begin{tabular}{ll}
\hline Component & $\%$ \\
\hline Tricyclene & 0.1 \\
$\alpha$-Pinene & 9.6 \\
Camphene & 2.9 \\
Oct-1-en-3-ol & 0.2 \\
$\beta$-Pinene & 3.4 \\
Myrcene & 1.3 \\
$\alpha$-Terpinene & 0.4 \\
p-Cymene & 1.7 \\
Limonene & 1.5 \\
$1,8-$ Cineol & 52.1 \\
$\gamma$-Terpinene & 0.5 \\
Terpinolene & 0.2 \\
Linalol & 0.9 \\
Camphre & 14.0 \\
$\delta$-Terpineol & 0.9 \\
Borneol & 2.9 \\
Terpinen-4-ol & 1.3 \\
$\alpha$-Terpineol & 4.8 \\
Verbenone & 0.1 \\
(E)- $\beta$-Caryophyllene & 0.4 \\
Caryophyllene oxide & 0.1 \\
Total composition & 99.3 \\
& \\
\hline
\end{tabular}

\section{Rationale}

The use of acids, alkaline and salts solutions in industries causes serious corrosion attacks on metallic structure surface, such as carbon steel, stainless steel and aluminum [1-4]. This has caused tremendous financial misfortunes to the industries. These issues had inspired researchers to look for ways of controlling corrosion which had led to the utilization of corrosion inhibitors as a recognizable strategy to control corrosion [5]. Inhibitor molecules are absorbed by metal surface $[6,7]$. The excellent anticorrosion potential for metal surface were the chemical compounds having in their structure atoms

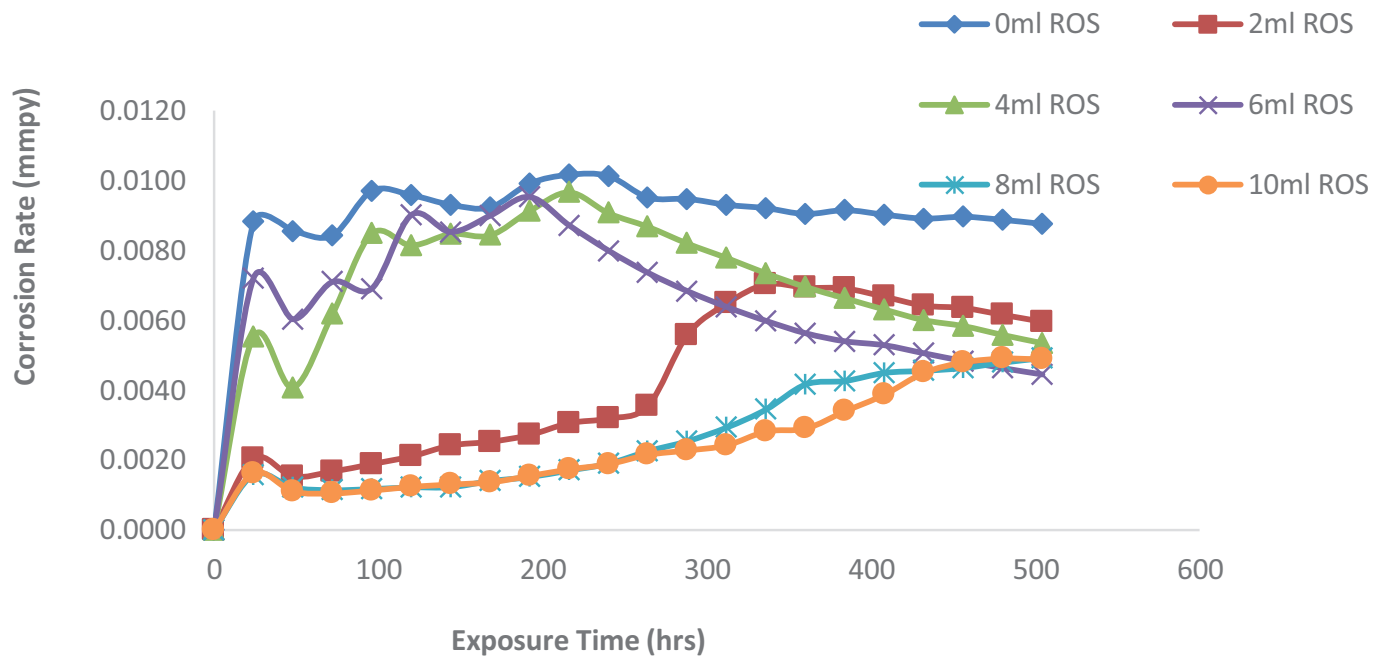

Fig. 1. Corrosion rate for Citric acid solution and RO within $504 \mathrm{~h}$. 
Table 3

Experimental data of Corrosion rate for HCS achieved during $504 \mathrm{~h}$ of immersion in Citric media at 0-10 ml RO concentrations.

\begin{tabular}{lllllll}
\hline Time $(\mathrm{h})$ & Control & $2 \mathrm{ml}$ & $4 \mathrm{ml}$ & $6 \mathrm{ml}$ & $8 \mathrm{ml}$ & $10 \mathrm{ml}$ \\
\hline 0 & 0.0000 & 0.0000 & 0.0000 & 0.0000 & 0.0000 & 0.0000 \\
24 & 0.0088 & 0.0020 & 0.0055 & 0.0072 & 0.0016 & 0.0016 \\
48 & 0.0085 & 0.0015 & 0.0041 & 0.0060 & 0.0012 & 0.0011 \\
72 & 0.0084 & 0.0017 & 0.0062 & 0.0071 & 0.0011 & 0.0011 \\
96 & 0.0097 & 0.0019 & 0.0085 & 0.0069 & 0.0012 & 0.0011 \\
120 & 0.0096 & 0.0021 & 0.0081 & 0.0090 & 0.0012 & 0.0012 \\
144 & 0.0093 & 0.0024 & 0.0085 & 0.0085 & 0.0012 & 0.0013 \\
168 & 0.0092 & 0.0025 & 0.0084 & 0.0090 & 0.0014 & 0.0014 \\
192 & 0.0099 & 0.0027 & 0.0091 & 0.0095 & 0.0015 & 0.0015 \\
216 & 0.0102 & 0.0031 & 0.0097 & 0.0087 & 0.0017 & 0.0017 \\
240 & 0.0101 & 0.0032 & 0.0091 & 0.0080 & 0.0019 & 0.0019 \\
264 & 0.0095 & 0.0036 & 0.0087 & 0.0074 & 0.0023 & 0.0022 \\
288 & 0.0095 & 0.0056 & 0.0082 & 0.0068 & 0.0025 & 0.0023 \\
312 & 0.0093 & 0.0065 & 0.0078 & 0.0064 & 0.0029 & 0.0024 \\
336 & 0.0092 & 0.0070 & 0.0073 & 0.0060 & 0.0035 & 0.0028 \\
360 & 0.0090 & 0.0069 & 0.0070 & 0.0056 & 0.0042 & 0.0029 \\
384 & 0.0091 & 0.0069 & 0.0066 & 0.0054 & 0.0043 & 0.0034 \\
408 & 0.0090 & 0.0067 & 0.0063 & 0.0053 & 0.0045 & 0.0039 \\
432 & 0.0089 & 0.0064 & 0.0060 & 0.0051 & 0.0046 & 0.0045 \\
456 & 0.0090 & 0.0064 & 0.0058 & 0.0048 & 0.0046 & 0.0044 \\
480 & 0.0089 & 0.0062 & 0.0056 & 0.0046 & 0.0048 & 0.0046 \\
504 & 0.0088 & 0.0060 & 0.0053 & 0.0044 & 0.0045 & 0.0049 \\
\hline
\end{tabular}

Table 4

Experimental data of Corrosion rate for HCS achieved during $504 \mathrm{~h}$ of immersion in Sulphuric acid media at $0-10 \mathrm{ml}$ RO concentrations.

\begin{tabular}{lllllll}
\hline Time $(\mathrm{h})$ & Control & $2 \mathrm{ml}$ & $4 \mathrm{ml}$ & $6 \mathrm{ml}$ & $8 \mathrm{ml}$ & $10 \mathrm{ml}$ \\
\hline 0 & 0 & 0 & 0 & 0.0000 & 0.0000 & 0.0000 \\
24 & 0.0549 & 0.0432 & 0.0167 & 0.0338 & 0.0380 & 0.0226 \\
48 & 0.0509 & 0.0430 & 0.0203 & 0.0304 & 0.0457 & 0.0219 \\
72 & 0.0396 & 0.0365 & 0.0209 & 0.0238 & 0.0329 & 0.0210 \\
96 & 0.0463 & 0.0275 & 0.0203 & 0.0229 & 0.0250 & 0.0184 \\
120 & 0.0425 & 0.0222 & 0.0179 & 0.0214 & 0.0203 & 0.0155 \\
144 & 0.0357 & 0.0186 & 0.0153 & 0.0201 & 0.0171 & 0.0128 \\
168 & 0.0305 & 0.0161 & 0.0131 & 0.0184 & 0.0149 & 0.0112 \\
192 & 0.0335 & 0.0143 & 0.0116 & 0.0162 & 0.0131 & 0.0098 \\
216 & 0.0329 & 0.0130 & 0.0104 & 0.0144 & 0.0118 & 0.0088 \\
240 & 0.0301 & 0.0139 & 0.0110 & 0.0130 & 0.0134 & 0.0095 \\
264 & 0.0274 & 0.0127 & 0.0109 & 0.0119 & 0.0122 & 0.0090 \\
288 & 0.0300 & 0.0117 & 0.0105 & 0.0110 & 0.0112 & 0.0083 \\
312 & 0.0299 & 0.0109 & 0.0098 & 0.0102 & 0.0104 & 0.0077 \\
336 & 0.0284 & 0.0102 & 0.0091 & 0.0095 & 0.0098 & 0.0072 \\
360 & 0.0264 & 0.0096 & 0.0085 & 0.0089 & 0.0092 & 0.0068 \\
384 & 0.0281 & 0.0113 & 0.0087 & 0.0084 & 0.0099 & 0.0072 \\
408 & 0.0277 & 0.0106 & 0.0087 & 0.0080 & 0.0094 & 0.0072 \\
432 & 0.0264 & 0.0101 & 0.0085 & 0.0083 & 0.0090 & 0.0069 \\
456 & 0.0276 & 0.0098 & 0.0083 & 0.0081 & 0.0086 & 0.0065 \\
480 & 0.0276 & 0.0093 & 0.0079 & 0.0078 & 0.0082 & 0.0062 \\
504 & 0.0275 & 0.0090 & 0.0075 & 0.0076 & 0.0080 & 0.0059 \\
\hline
\end{tabular}

with unoccupied electron pair like phosphorous, sulfur, nitrogen or oxygen incorporated in a resonance system and groups with electron efficiency that push electron by inductive effect. Recently, researchers have been working on green inhibitors (environmentally friendly) to stay away from the harmful impact of prepared inhibitors [8-10]. These inhibitors are found to be extremely active in corrosive solutions moreover they are financial valuable and eco-friendly [11-16]. For the same reason, different plant extracts are also investigated. To this end, the utilization of eco-friendly organic compounds with atoms having unpaired electron pairs or conjugated pi-system as inhibitors to reduce corrosion attack has gotten definite consideration [17-20]. These organic inhibitors act as anodic, cathodic or mixed type, thereby retarding and forming film protection/barrier on the surface of the steel samples for effective and efficient performance. This research reveals the data obtained from the experimental analysis of inhibitive mechanism of Rosmarinus officinalis (RO) essential oil on high carbon steel (HCS) in three different corrosive environment of sodium chloride, sulphuric acid and citric acid solution. 
Table 5

Experimental data of Corrosion rate for HCS achieved during $504 \mathrm{~h}$ of immersion in Sodium chloride media at $0-10 \mathrm{ml}$ RO concentrations.

\begin{tabular}{lllllll}
\hline Time $(\mathrm{h})$ & Control & $2 \mathrm{ml}$ & $4 \mathrm{ml}$ & $6 \mathrm{ml}$ & $8 \mathrm{ml}$ & $10 \mathrm{ml}$ \\
\hline 0 & 0 & 0 & 0 & 0 & 0 & 0 \\
24 & 0.00318 & 0.00015 & 0.00045 & 0.00025 & 0.00038 & 0.00009 \\
48 & 0.00241 & 0.00039 & 0.00028 & 0.00020 & 0.00012 & 0.00026 \\
72 & 0.00261 & 0.00043 & 0.00051 & 0.00022 & 0.00014 & 0.00028 \\
96 & 0.00152 & 0.00035 & 0.00023 & 0.00024 & 0.00018 & 0.00021 \\
120 & 0.00181 & 0.00069 & 0.00033 & 0.00019 & 0.00017 & 0.00015 \\
144 & 0.00167 & 0.00036 & 0.00037 & 0.00032 & 0.00020 & 0.00027 \\
168 & 0.00146 & 0.00039 & 0.00041 & 0.00012 & 0.00018 & 0.00024 \\
192 & 0.00138 & 0.00014 & 0.00040 & 0.00009 & 0.00015 & 0.00021 \\
216 & 0.00144 & 0.00021 & 0.00042 & 0.00009 & 0.00007 & 0.00019 \\
240 & 0.00126 & 0.00028 & 0.00045 & 0.00012 & 0.00014 & 0.00020 \\
264 & 0.00161 & 0.00030 & 0.00048 & 0.00013 & 0.00021 & 0.00026 \\
288 & 0.00212 & 0.00122 & 0.00084 & 0.00030 & 0.00011 & 0.00023 \\
312 & 0.00238 & 0.00100 & 0.00092 & 0.00019 & 0.00014 & 0.00027 \\
336 & 0.00301 & 0.00121 & 0.00092 & 0.00025 & 0.00013 & 0.00023 \\
360 & 0.00370 & 0.00131 & 0.00103 & 0.00026 & 0.00015 & 0.00025 \\
384 & 0.00486 & 0.00142 & 0.00092 & 0.00025 & 0.00015 & 0.00025 \\
408 & 0.00544 & 0.00150 & 0.00081 & 0.00029 & 0.00016 & 0.00027 \\
432 & 0.00609 & 0.00151 & 0.00087 & 0.00033 & 0.00017 & 0.00027 \\
456 & 0.00648 & 0.00153 & 0.00083 & 0.00029 & 0.00012 & 0.00027 \\
480 & 0.00671 & 0.00166 & 0.00080 & 0.00030 & 0.00015 & 0.00024 \\
504 & 0.00726 & 0.00214 & 0.00075 & 0.00048 & 0.00015 & 0.00024 \\
\hline
\end{tabular}

Table 6

Experimental data of Inhibitor efficiency for HCS achieved during $504 \mathrm{~h}$ of immersion in Citric media at 0-10 $\mathrm{ml} \mathrm{RO}$ concentrations.

\begin{tabular}{llllll}
\hline Time $(\mathrm{h})$ & $2 \mathrm{ml}$ & $4 \mathrm{ml}$ & $6 \mathrm{ml}$ & $8 \mathrm{ml}$ & $10 \mathrm{ml}$ \\
\hline 24 & 76.84 & 37.24 & 18.36 & 82.08 & 81.56 \\
48 & 82.06 & 52.30 & 29.53 & 85.80 & 87.06 \\
72 & 80.13 & 26.64 & 15.78 & 86.45 & 87.52 \\
96 & 80.54 & 12.48 & 28.80 & 87.91 & 88.33 \\
120 & 77.99 & 14.89 & 5.97 & 87.25 & 87.07 \\
144 & 74.00 & 8.84 & 8.39 & 86.81 & 85.99 \\
168 & 72.62 & 8.55 & 2.59 & 84.81 & 85.16 \\
192 & 72.58 & 7.82 & 3.91 & 84.69 & 84.37 \\
216 & 69.89 & 4.82 & 14.26 & 83.22 & 82.89 \\
240 & 68.49 & 10.38 & 21.11 & 81.22 & 81.35 \\
264 & 62.65 & 8.69 & 22.65 & 76.28 & 77.32 \\
288 & 41.01 & 13.37 & 27.89 & 73.15 & 75.91 \\
312 & 30.32 & 16.25 & 31.46 & 68.44 & 73.89 \\
336 & 23.61 & 20.15 & 35.06 & 62.48 & 69.28 \\
360 & 23.28 & 23.03 & 37.77 & 53.89 & 67.82 \\
384 & 24.45 & 27.45 & 41.02 & 53.35 & 62.77 \\
408 & 26.01 & 30.00 & 41.43 & 50.12 & 56.95 \\
432 & 27.92 & 32.51 & 43.27 & 48.83 & 49.39 \\
456 & 29.09 & 34.80 & 46.07 & 48.23 & 46.35 \\
480 & 30.60 & 37.03 & 47.82 & 45.96 & 44.61 \\
504 & 31.94 & 38.88 & 49.21 & 43.80 & 44.12 \\
\hline
\end{tabular}

\section{Experimental procedure}

18 samples of high carbon steel (HCS) were cut into same size of cylindrical shape and prepared for three (3) corrosive environment of sodium chloride, sulphuric acid and citric acid solution. Emery paper was used to grind the surface of 18 samples with 120, 220, 800, 1000, 1200 grits before lowering them into the three (3) corrosive environment for weight loss measurement within 504 h. $0.5 \mathrm{M}$ concentration were prepared for both sulphuric acid and citric acid solution and 3.5\% $\mathrm{w} / \mathrm{v}$ of $\mathrm{NaCl}$ solution was prepared by dissolving $3.5 \mathrm{~g}$ of the salt in $100 \mathrm{ml}$ of distilled water. The corrosive environments were mixed with Rosmarinus officinalis (RO) essential oil as inhibitor in the proportion of $0 \mathrm{ml}, 2 \mathrm{ml}, 4 \mathrm{ml}, 6 \mathrm{ml}, 8 \mathrm{ml}$ and $10 \mathrm{ml}$ concentration. The samples were suspended into the corrosive solutions for weight loss analysis and measurement were recorded at the intervals of 24 has displayed in some of the tables below. The weight loss measurement was achieved by Ohaus weighing balance. The experimental analysis of the research was performed at ambient temperature $\left(25{ }^{\circ} \mathrm{C}\right)$. The results obtained during the $504 \mathrm{~h}$ at $24 \mathrm{~h}$ interval recording was tabulated in Tables 3-8 below with both corrosion rate and inhibition efficiencies with initial weight of samples in each corrosive environment. The formulars used in achieving 
Table 7

Experimental data of Inhibitor efficiency for HCS achieved during $504 \mathrm{~h}$ of immersion in Sulphuric acid media at $0-10 \mathrm{ml}$ RO concentrations.

\begin{tabular}{llllll}
\hline Time $(\mathrm{h})$ & $2 \mathrm{ml}$ & $4 \mathrm{ml}$ & $6 \mathrm{ml}$ & $8 \mathrm{ml}$ & $10 \mathrm{ml}$ \\
\hline 24 & 21.35 & 69.65 & 38.52 & 30.80 & 58.80 \\
48 & 15.63 & 60.13 & 40.26 & 10.34 & 57.08 \\
72 & 7.858 & 47.12 & 39.91 & 16.88 & 46.87 \\
96 & 40.53 & 56.20 & 50.60 & 46.07 & 60.19 \\
120 & 47.77 & 57.91 & 49.62 & 52.18 & 63.53 \\
144 & 47.85 & 57.08 & 43.73 & 52.06 & 64.08 \\
168 & 47.15 & 57.04 & 39.81 & 51.35 & 63.47 \\
192 & 57.43 & 65.49 & 51.74 & 60.85 & 70.85 \\
216 & 60.41 & 68.44 & 56.37 & 64.22 & 73.28 \\
240 & 53.85 & 63.52 & 56.77 & 55.69 & 68.64 \\
264 & 53.43 & 60.33 & 56.55 & 55.41 & 67.22 \\
288 & 60.91 & 65.12 & 63.49 & 62.59 & 72.47 \\
312 & 63.51 & 67.30 & 66.00 & 65.11 & 74.15 \\
336 & 64.04 & 68.03 & 66.50 & 65.62 & 74.68 \\
360 & 63.59 & 67.76 & 66.11 & 65.17 & 74.31 \\
384 & 59.86 & 69.02 & 69.98 & 64.65 & 74.42 \\
408 & 61.55 & 68.68 & 71.11 & 66.01 & 74.11 \\
432 & 61.66 & 67.66 & 68.47 & 66.09 & 74.04 \\
456 & 64.59 & 69.93 & 70.62 & 68.91 & 76.44 \\
480 & 66.28 & 71.43 & 71.77 & 70.26 & 77.60 \\
504 & 67.41 & 72.60 & 72.68 & 70.81 & 78.45 \\
\hline
\end{tabular}

Table 8

Experimental data of Corrosion rate for HCS achieved during $504 \mathrm{~h}$ of immersion in Sodium Chloride media at $0-10 \mathrm{ml} \mathrm{RO}$ concentrations.

\begin{tabular}{llllll}
\hline Time $(\mathrm{h})$ & $2 \mathrm{ml}$ & $4 \mathrm{ml}$ & $6 \mathrm{ml}$ & $8 \mathrm{ml}$ & $10 \mathrm{ml}$ \\
\hline 0 & 0.00 & 0.00 & 0.00 & 0.00 & 0.00 \\
24 & 95.16 & 85.71 & 92.01 & 88.14 & 97.09 \\
48 & 83.65 & 88.30 & 91.51 & 95.03 & 89.10 \\
72 & 83.53 & 80.57 & 91.62 & 94.67 & 89.25 \\
96 & 76.74 & 84.70 & 84.32 & 88.24 & 86.09 \\
120 & 61.74 & 81.55 & 89.33 & 90.44 & 91.80 \\
144 & 78.49 & 77.88 & 81.11 & 88.25 & 84.10 \\
168 & 73.45 & 72.17 & 91.55 & 87.93 & 83.79 \\
192 & 90.17 & 70.85 & 93.44 & 89.12 & 84.52 \\
216 & 85.49 & 70.57 & 93.88 & 94.83 & 87.16 \\
240 & 78.02 & 64.46 & 90.79 & 88.77 & 84.41 \\
264 & 81.20 & 69.82 & 91.93 & 87.09 & 83.99 \\
288 & 42.53 & 60.44 & 85.79 & 94.61 & 88.97 \\
312 & 57.88 & 61.61 & 91.89 & 94.06 & 88.76 \\
336 & 59.73 & 69.34 & 91.67 & 95.82 & 92.31 \\
360 & 64.73 & 72.28 & 93.06 & 95.99 & 93.17 \\
384 & 70.82 & 81.11 & 94.82 & 96.93 & 94.81 \\
408 & 72.40 & 85.06 & 94.62 & 97.00 & 95.11 \\
432 & 75.22 & 85.75 & 94.58 & 97.15 & 95.55 \\
456 & 76.43 & 87.18 & 95.53 & 98.11 & 95.86 \\
480 & 75.31 & 88.05 & 95.46 & 97.81 & 96.44 \\
504 & 70.49 & 89.63 & 93.32 & 97.87 & 96.66 \\
\hline
\end{tabular}

the data from the experiment for the 21 days analysis, such as weigh loss, corrosion rate and surface coverage are all stated below

$\mathrm{WL}=\mathrm{Wi}-\mathrm{Wa}$, where $\mathrm{Wi}$ is the weight loss of the initial weight before immersion and Wa is the weight loss after immersion into the acidic solution

$$
\theta_{s}=1-\frac{W L_{n}}{W L_{i}}
$$

$\theta_{\mathrm{s}}$ denotes the degree of the oil adsorbed for each gram of surface of steel. $\mathrm{W}_{\mathrm{n}}$ is the weight loss of the sample in the non-inhibited solution and $\mathrm{W}_{\mathrm{i}}$ is the weight loss of the sample in the inhibited solution.

The inhibitor efficiency is calculated as:

$$
\% I E=\theta_{s} \times 100
$$




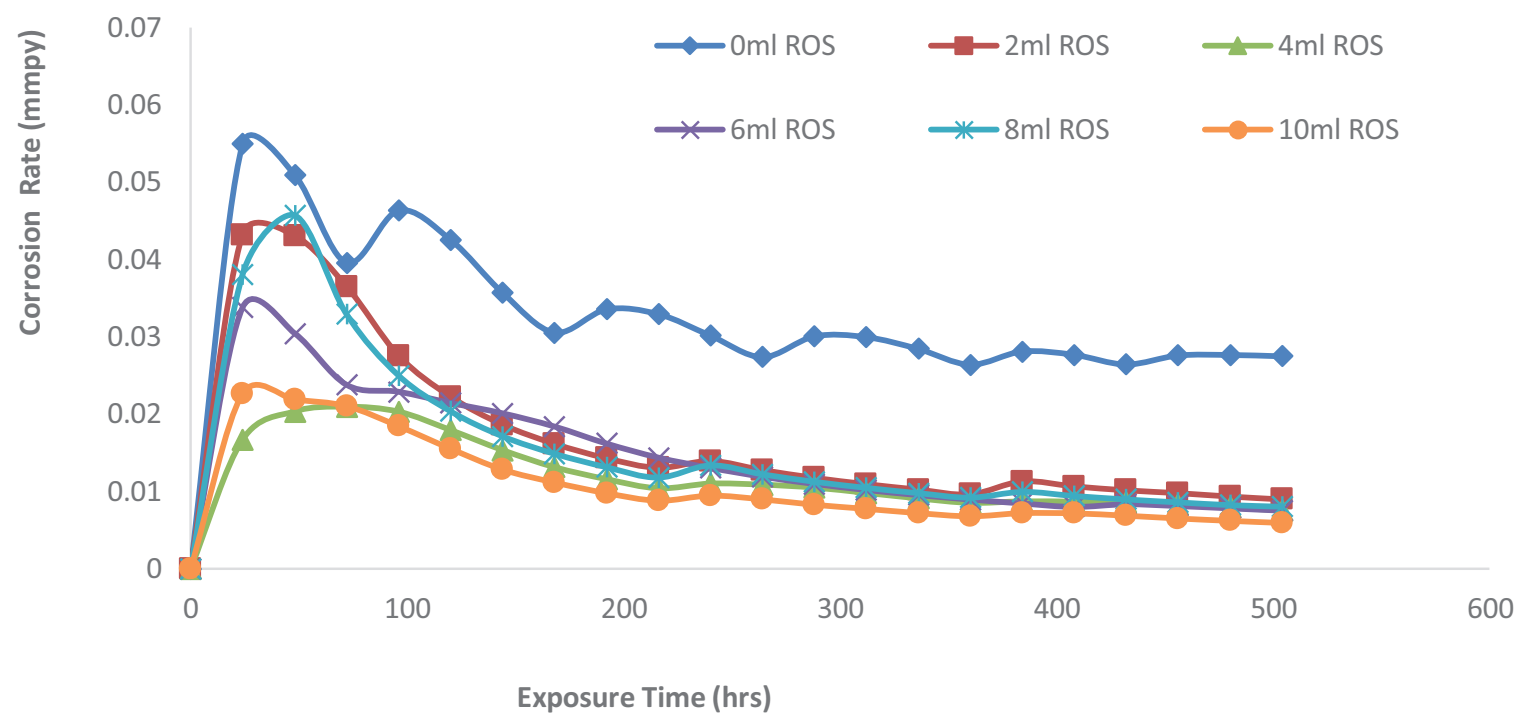

Fig. 2. Corrosion rate for Sulfur acid solution and RO within $504 \mathrm{~h}$.

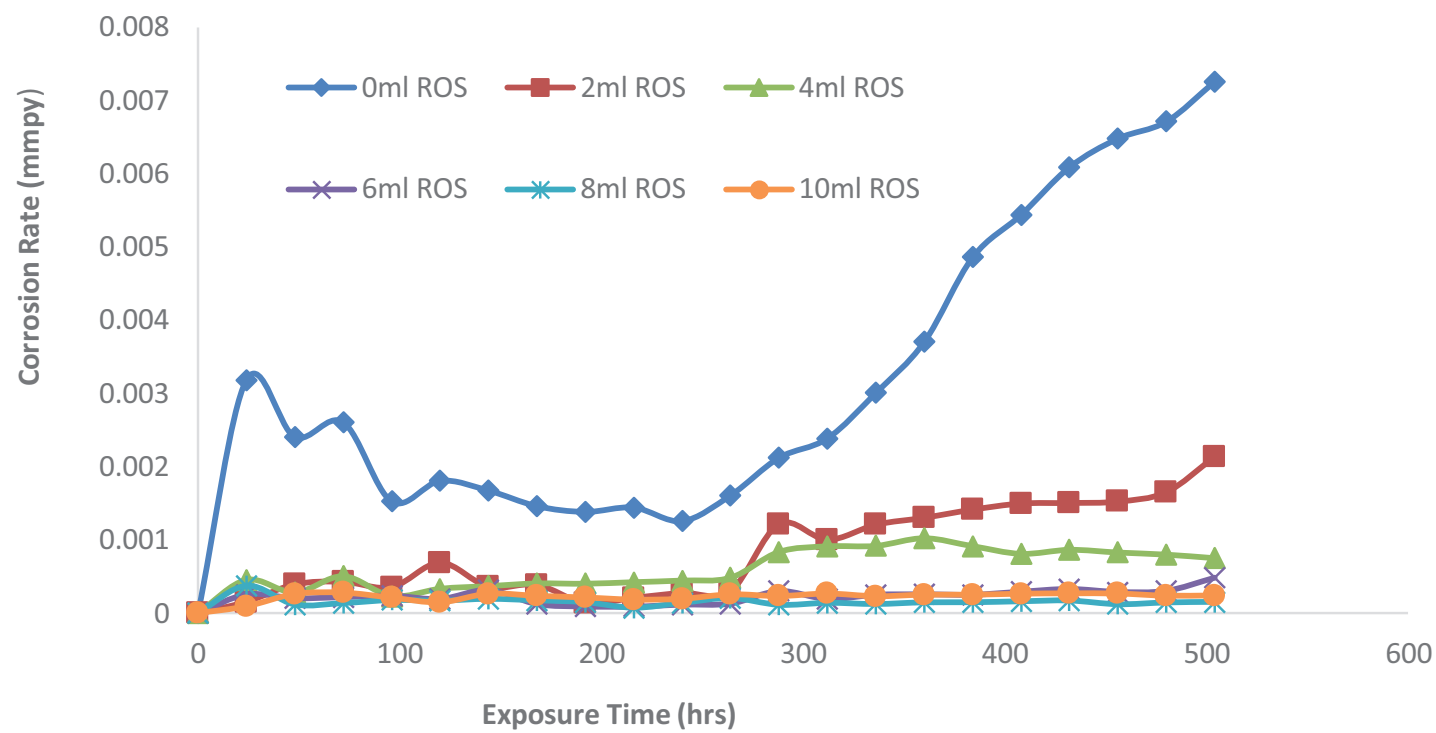

Fig. 3. Corrosion rate for Sodium chloride solution and RO within $504 \mathrm{~h}$.

The rate of corrosion, $\mathrm{C}$ expressed in $\mathrm{mm} / \mathrm{y}$ is calculated as:

$$
C=\frac{87.6 * W L}{D * A_{s} * T_{e}}
$$

where WL is the weight loss $(\mathrm{g}), T_{\mathrm{e}}$ is the exposure time $(\mathrm{h}), \mathrm{A}_{\mathrm{s}}$ is surface area of steel surface $\left(\mathrm{cm}^{2}\right), D$ is the steel density $\left(\mathrm{g} / \mathrm{cm}^{2}\right)$.

Fig. 7(a)-(s) shows the optical images of HCS samples: a) before immersion, b) in $0.5 \mathrm{M}$ citric acid with no inhibitor, c) in $0.5 \mathrm{M}$ citric acid with $2 \mathrm{ml}$ inhibitor, d) in $0.5 \mathrm{M}$ citric acid with $4 \mathrm{ml}$ inhibitor, e) in $0.5 \mathrm{M}$ citric acid with $6 \mathrm{ml}$ inhibitor, f) in $0.5 \mathrm{M}$ citric acid with $8 \mathrm{ml}$ inhibitor, g) in $0.5 \mathrm{M}$ citric acid with $10 \mathrm{ml}$ inhibitor, h) in $0.5 \mathrm{M} \mathrm{H}_{2} \mathrm{SO}_{4}$ with no inhibitor, i) in $0.5 \mathrm{M} \mathrm{H}_{2} \mathrm{SO}_{4}$ with $2 \mathrm{ml}$ inhibitor, $\mathrm{j}$ ) in $0.5 \mathrm{M} \mathrm{H}_{2} \mathrm{SO}_{4}$ with $4 \mathrm{ml}$ inhibitor, $\mathrm{k}$ ) in $0.5 \mathrm{M} \mathrm{H}_{2} \mathrm{SO}_{4}$ with $6 \mathrm{ml}$ inhibitor, l) in $0.5 \mathrm{M} \mathrm{H}_{2} \mathrm{SO}_{4}$ with $8 \mathrm{ml}$ inhibitor, $\mathrm{m}$ ) in $0.5 \mathrm{M} \mathrm{H}_{2} \mathrm{SO}_{4}$ with $10 \mathrm{ml}$ inhibitor, $\mathrm{n}$ ) in 3.5wt\% NaCl with no inhibitor, o) in 3.5wt\% $\mathrm{NaCl}$ with $2 \mathrm{ml}$ inhibitor, p) in $3.5 \mathrm{wt} \% \mathrm{NaCl}$ with $4 \mathrm{ml}$ inhibitor, q) in $3.5 \mathrm{wt} \% \mathrm{NaCl}$ with $6 \mathrm{ml}$ inhibitor, r) in $3.5 \mathrm{wt} \% \mathrm{NaCl}$ with $8 \mathrm{ml}$ inhibitor, s) in $3.5 \mathrm{wt} \% \mathrm{NaCl}$ with $10 \mathrm{ml}$ inhibitor. 


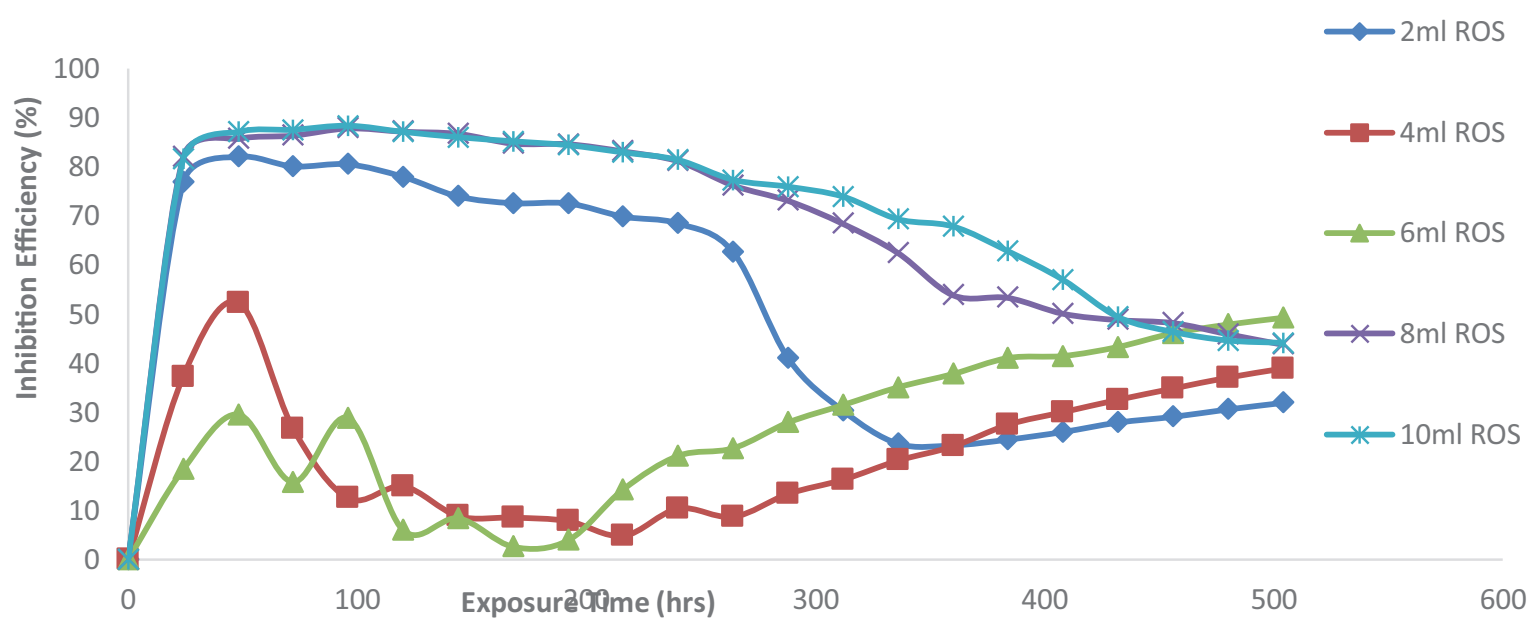

Fig. 4. IE\% for Citric acid solution and RO within $504 \mathrm{~h}$.

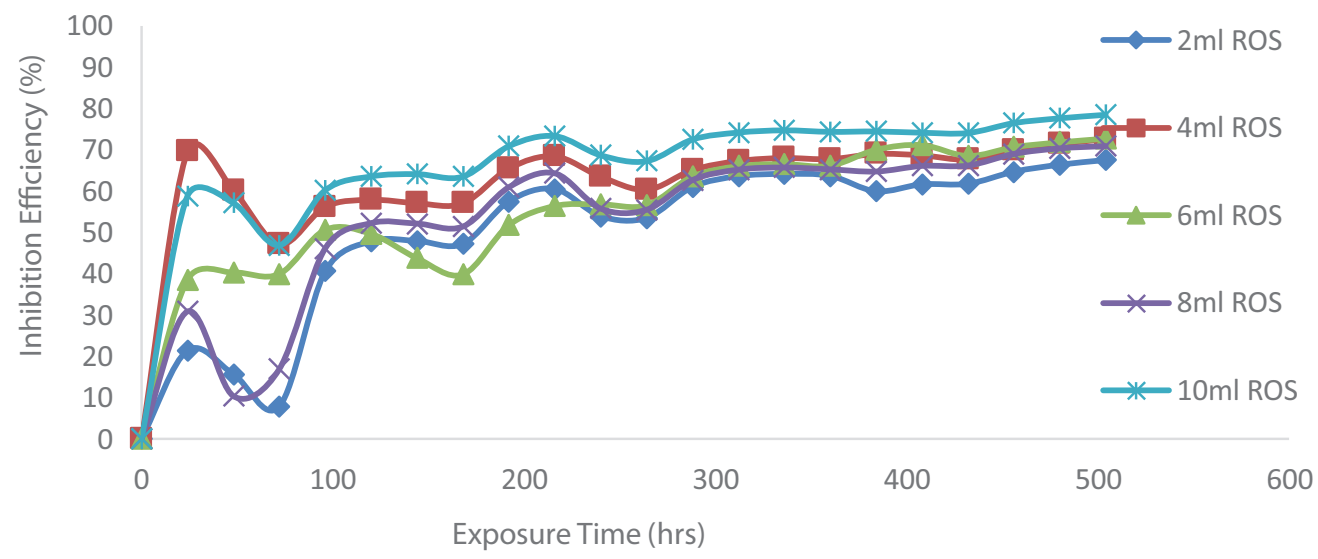

Fig. 5. IE\% for Sulphuric acid solution and RO within $504 \mathrm{~h}$.

\section{Data, value and validation}

The above data in Tables 3-8 show the values of corrosion rate and inhibitor efficiencies of high carbon steel in $0.5 \mathrm{M}$ Citric acid $\left(\mathrm{C}_{6} \mathrm{H}_{8} \mathrm{O}_{7}\right), 0.5 \mathrm{M}$ Sulphuric acid $\left(\mathrm{H}_{2} \mathrm{SO}_{4}\right)$ and Sodium Chloride $(\mathrm{NaCl})$ solutions with $2-10 \mathrm{ml}$ RO concentrations. The results of Tables 3-5 show that optimum corrosion rate of $\mathrm{HCS}$ occurred at $0 \mathrm{ml} \mathrm{RO}$ samples in $\mathrm{Citric}$ acid $\left(\mathrm{C}_{6} \mathrm{H}_{8} \mathrm{O}_{7}\right)$, Sulphuric acid $\left(\mathrm{H}_{2} \mathrm{SO}_{4}\right)$ and Sodium Chloride $(\mathrm{NaCl})$ as compared with other samples of each corrosive environments. This suggest severe corrosion attack of redox reaction on HCS $0 \mathrm{ml}$ RO samples of each corrosive environment due to the absence of RO inhibitor. The corrosion rate value increases for each of the corrosive environment as the immersion time increases and at a time its retarded and later increases again until it became stable toward the end of $504 \mathrm{~h}$. The inhibited samples of 2-10 ml OR samples show significant decrease in corrosion rate in the three (3) corrosive environments with the lowest corrosion rate values occurring in $\mathrm{NaCl}$ solution, follow by $\mathrm{C}_{6} \mathrm{H}_{8} \mathrm{O}_{7}$ and then $\mathrm{H}_{2} \mathrm{SO}_{4}$ solution, which show the highest corrosion rate value. This suggest that Sulphuric acid solution initiated strong severe adsorption effect on HCS than the two (2) corrosive environments due to the presence of active site of $\mathrm{SO}_{4}{ }^{-2}$ anion. Furthermore, the inhibitor efficiency values of each of the corrosive environment as shown in Tables 6-8, corresponds to the reduction in corrosion rate of $\mathrm{NaCl}$ solution with optimum inhibitor efficiency values compared with the other corrosive solutions and also responsible for the lowest corrosion rate of $\mathrm{HCS}$ in $\mathrm{NaCl}$ solution for all the HCS samples of 2-10 ml OR organic inhibitor at 504 h. Table 8 reveals the highest performance value of OR organic inhibitor with inhibition performance of $70 \%$ above with $\mathrm{HCS}$ samples in $\mathrm{NaCl}$ solution within $504 \mathrm{~h}$ of immersion time. Also, Tables 6 and 7 shows that HCS samples performed with excellent adsorption on the surface of the samples in Citric $\left(\mathrm{C}_{6} \mathrm{H}_{8} \mathrm{O}_{7}\right)$ and Sulphuric $\left(\mathrm{H}_{2} \mathrm{SO}_{4}\right)$ solution within the range of 40-78\% inhibitor efficiency. 


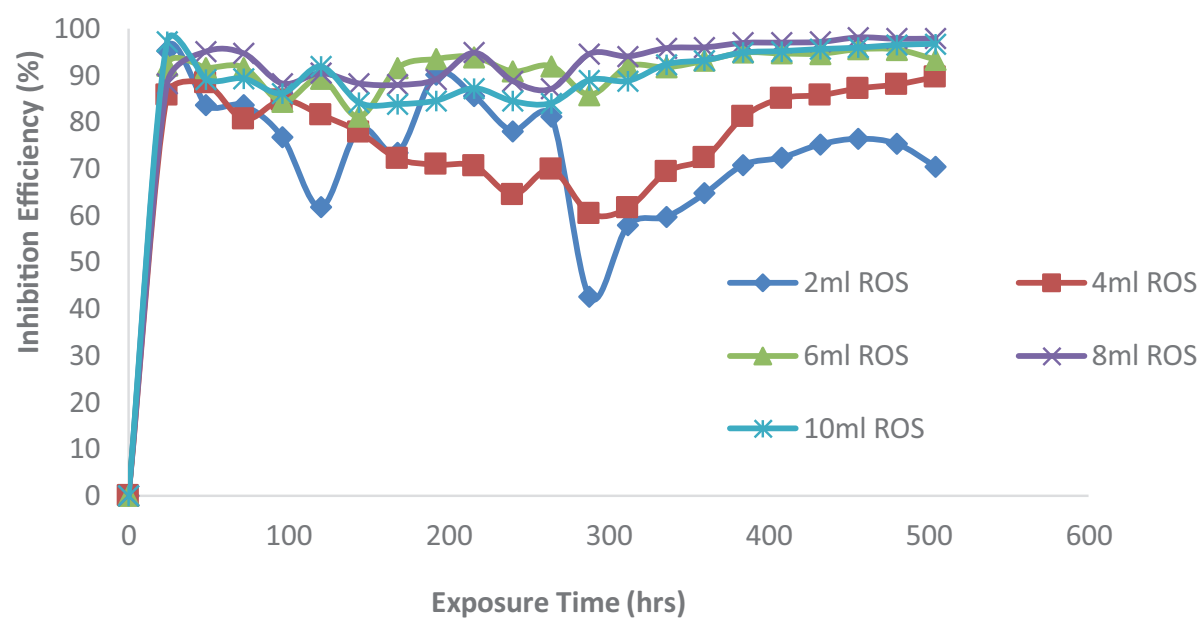

Fig. 6. IE\% for Sodium chloride solution and RO within $504 \mathrm{~h}$.

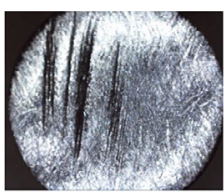

(a)
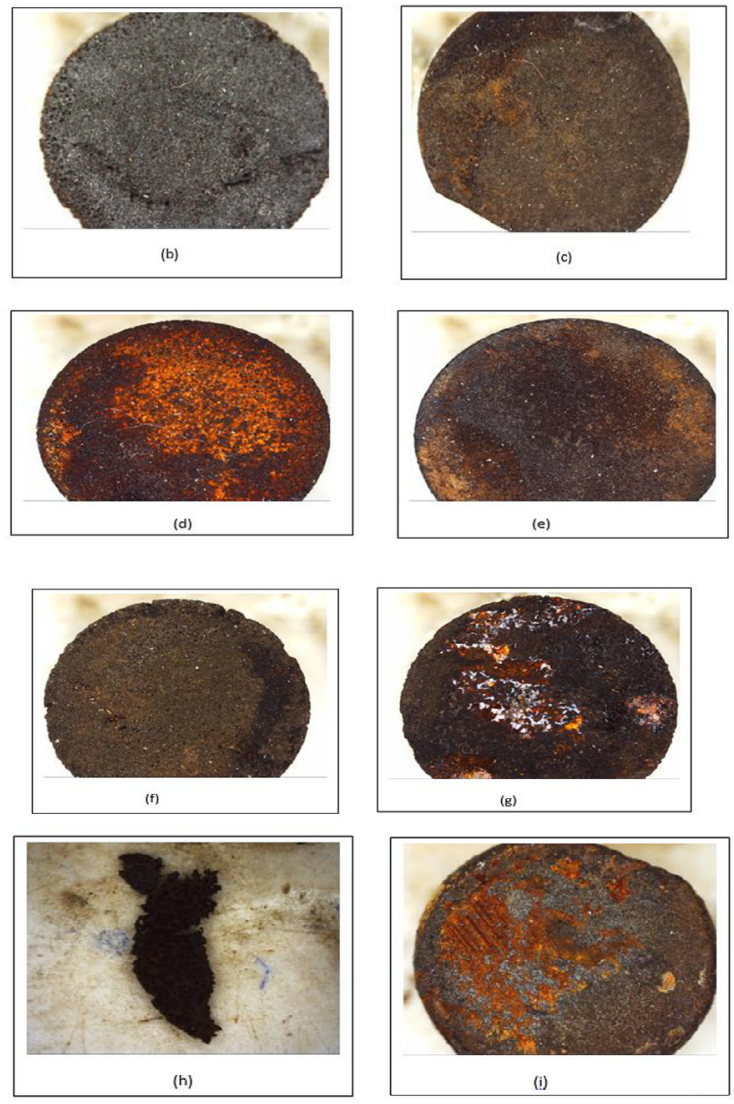

Fig. 7. (a)

(b-g) The following images were obtained for steel samples immersed in citric acid medium for different inhibitor concentrations:

(h-m) The following images were obtained for steel samples immersed in sulphuric acid medium for different inhibitor concentrations. $(\mathrm{n}-\mathrm{s})$ The following images were obtained for steel samples immersed in sodium chloride medium for different inhibitor concentrations. 

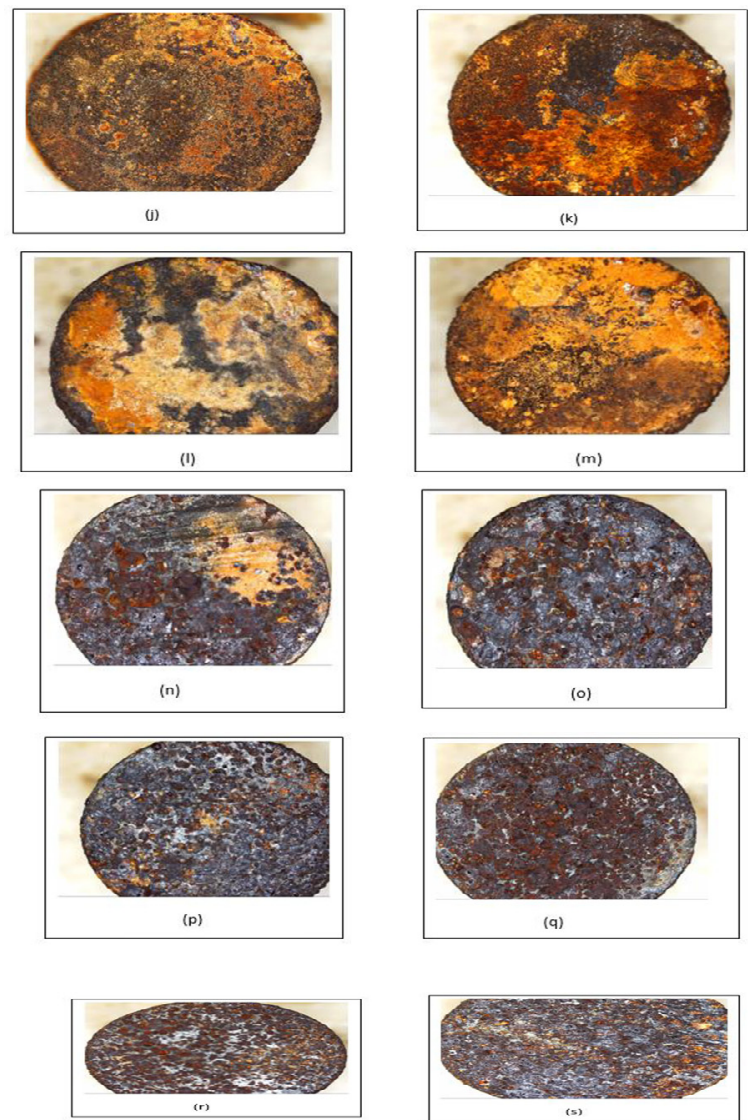

Fig. 7. Continued

\section{Declaration of Competing Interest}

None.

\section{Acknowledgement}

The author acknowledges Covenant University, Ota, Nigeria for the full support and research facilities offered for this research and publication.

\section{Supplementary materials}

Supplementary material associated with this article can be found, in the online version, at doi:10.1016/j.cdc.2021.100660.

\section{References}

[1] D.B. Hmamou, M.R. Aouad, R. Salghi, A. Zarrouk, M. Assouag, O. Benali, ... B. Hammouti, Inhibiting effects 4, 5-diphenyl-1H-imidazole-2-thiol for C38 steel in 1M HCl: electrochemical study, J. Chem. Pharm. Res. 4 (7) (2012) 3489-3497.

[2] M.A. Fajobi, R.T. Loto, O.O. Oluwole, Steel corrosion behavior in acidic solution for application in petrochemical distillation systems, IOP Conference Series: Materials Science and Engineering 811 (1) 012030.

[3] O.A. Odunlami, O.T. Olomukoro, R.T. Loto, Corrosion inhibition of rosemary oil on high carbon steel in sulphuric acid medium.

[4] M.A. Fajobi, R.T. Loto, O.O. Oluwole, Crude distillation overhead system": corrosion and Control, J. Phys. 1378 (4) (2019) 042090 IOP Publishing.

[5] M.A. Fajobi, R.T. Loto, O.O. Oluwole, Corrosion in crude distillation overhead system: a review, J. Bio-and Tribo-Corros. 5 (3) (2019) 67.

[6] C. Loganayagi, C. Kamal, M.G. Sethuraman, Opuntiol: an active principle of Opuntia elatior as an eco-friendly inhibitor of corrosion of mild steel in acid medium, ACS Sustain. Chem. Eng. 2 (4) (2014) 606-613.

[7] G. Ji, P. Dwivedi, S. Sundaram, R. Prakash, Inhibitive effect of chlorophytum borivilianum root extract on mild steel corrosion in $\mathrm{HCl}$ and $\mathrm{H}_{2} \mathrm{SO}_{4}$ solutions, Ind. Eng. Chem. Res. 52 (31) (2013) 10673-10681.

[8] P.B. Raja, M.G. Sethuraman, Natural products as corrosion inhibitor for metals in corrosive media-a review, Mater. Lett. 62 (1) (2008) 113-116.

[9] M.A. Chidiebere, C.E. Ogukwe, K.L. Oguzie, C.N. Eneh, E.E. Oguzie, Corrosion inhibition and adsorption behavior of Punica granatum extract on mild steel in acidic environments: experimental and theoretical studies, Ind. Eng. Chem. Res. 51 (2) (2012) 668-677.

[10] E.E. Oguzie, K.L. Oguzie, C.O. Akalezi, I.O. Udeze, J.N. Ogbulie, V.O. Njoku, Natural products for materials protection: corrosion and microbial growth inhibition using Capsicum frutescens biomass extracts, ACS Sustain. Chem. Eng. 1 (2) (2013) 214-225. 
[11] K. Krishnaveni, J. Ravichandran, A. Selvaraj, Effect of Morinda tinctoria leaves extract on the corrosion inhibition of mild steel in acid medium, Acta Metall. Sin. 26 (3) (2013) 321-327.

[12] P.B. Raja, M.G. Sethuraman, Inhibition of corrosion of mild steel in sulphuric acid medium by Calotropis procera. Pigment \& Resin Technology. P. B. Raja, M. G. Sethuraman, Pigm. Resin Technol. 38 (2009) (2009) 33.

[13] I.B. Obot, N.O. Obi-Egbedi, An interesting and efficient green corrosion inhibitor for aluminium from extracts of Chlomolaena odorata L. in acidic solution, J. Appl. Electrochem. 40 (11) (2010) 1977-1984.

[14] A.Y. Musa, A.B. Mohamad, A.A. Al-Amiery, L.T. Tien, Galvanic corrosion of aluminum alloy (Al2024) and copper in 1.0M hydrochloric acid solution, Korean J. Chem. Eng. 29 (6) (2012) 818-822.

[15] X.H. Li, S.D. Deng, H. Fu, Inhibition by Jasminum nudiflorum Lindl. Leaves extract of the corrosion of cold rolled steel in hydrochloric acid solution, J. Appl. Electrochem. 40 (9) (2010) 1641-1649.

[16] E.A. Noor, Potential of aqueous extract of Hibiscus sabdariffa leaves for inhibiting the corrosion of aluminum in alkaline solutions, J. Appl. Electrochem. 39 (9) (2009) 1465-1475.

[17] E.E. Oguzie, K.L. Oguzie, C.O. Akalezi, I.O. Udeze, J.N. Ogbulie, V.O. Njoku, Natural products for materials protection: corrosion and microbial growth inhibition using Capsicum frutescens biomass extracts, ACS Sustain. Chem. Eng. 1 (2) (2013) 214-225.

[18] M. Fajobi, O. Fayomi, Akande, O. Odunlami, Inhibitive performance of ibuprofen drug on mild steel in 0.5M of $\mathrm{H}_{2} \mathrm{SO}_{4}$ acid, J. Bio-and Tribo-Corros. 5 (3) (2019) 79.

[19] J. Zhao, G. Chen, The synergistic inhibition effect of oleic-based imidazoline and sodium benzoate on mild steel corrosion in a $\mathrm{CO}_{2}$-saturated brine solution, Electrochim. Acta 69 (2012) 247-255.

[20] A.H.M.J. Alobaidy, A. Kadhum, S. Al-Baghdadi, A. Al-Amiery, A. Kadhum, E. Yousif, A Mohamad, Eco-friendly corrosion inhibitor: experimental studies on the corrosion inhibition performance of creatinine for mild steel in $\mathrm{HCl}$ complemented with quantum chemical calculations, Int. J. Electrochem. Sci. 10 (2015) 3961-3972.

[21] R.T. Loto, E. Oghenerukewe, Inhibition studies of rosmarinus officinalis on the pitting corrosion resistance 439LL ferritic stainless steel in dilute sulphuric acid, Orient. J. Chem. 32 (5) (2016) 2813-2832. 